\title{
Performance of Front Line Demonstration on the Yield of Wheat in Hanumangarh District of Rajasthan, India
}

\author{
Akshaya Ghintala*, Bheiru Singh, Mukesh Kumar Verma and Manohar Lal \\ Krishi Vigyan Kendra, Nohar, Hanumangarh-II (Raj.), India \\ *Corresponding author
}

\section{A B S T R A C T}

\begin{tabular}{|l|}
\hline K e y w o r d s \\
Frontline demonstration, \\
Extension gap, \\
$\begin{array}{l}\text { Technology gap, } \\
\text { Technology index, } \\
\text { Wheat, Production } \\
\text { technology }\end{array}$ \\
\hline Article Info \\
\hline $\begin{array}{l}\text { Accepted: } \\
\text { 24 August } 2018 \\
\text { Available Online: } \\
\text { 10 September } 2018\end{array}$ \\
\hline
\end{tabular}

\section{Introduction}

Wheat (Triticum aestivam L.) is the world's most widely cultivated food crop. It is eaten in various forms by more than one thousand million human beings in the world (Iftikhar $e t$ al., 2002). Besides staple food for human beings, wheat straw also serves as good source of feed for animals (Sarwar et al., 2006). In India, wheat production was recorded as 95.91 million tonnes $(\mathrm{mt})$ from an area of $30 \mathrm{~m}$ ha in 2013-14 (Anonymous, 2014). It supplies 21 per cent of the per capita food energy and 18 per cent of dietary protein in the country (Balasubramanian et al., 2012).
Wheat $\{$ Triticum aestivam L. $\}$ is one of the important cereals Rabi crop grown in all over the Rajasthan. The low productivity of wheat crop is due to poor adoption of improved technologies of wheat by the farmers. Hence, the Krishi Vigyan Kendra, Nohar, Hanumgarh-II (Rajasthan) has organized frontline demonstrations with improved variety consecutive years) at farmer's field of different villages in area of 18 hectare on 45 locations (farmers). Thus, a total of 45 demonstrations were selected. The data were the average grain yield of wheat under demonstration plots was $4293 \mathrm{~kg} / \mathrm{ha}$ when compared to local check $3933 \mathrm{~kg} / \mathrm{ha}$. The average percentage increase in the yield over local check was $9.24 \%$ during the course of study. Technology gap and technology index ver hectare and $10.56 \%$, respectively. It is concluded that wide gap existed in potential and demonstration yield in high yielding wheat varieties due to technology and extension gap in Hanumangarh district of Rajasthan. 
and there is need to develop varieties which are responsive to limited irrigation conditions.

Frontline demonstration may play a very important role in proper transfer of technologies and changing scientific temperament of the famers. Frontline demonstration is the new concept of field demonstration evolved by the ICAR with the inception of the technology mission on oilseed crops during mid-eighties. The main objective of frontline demonstrations is to demonstrate newly released crop production and protection technologies and its management practices in the farmers filed under different agro-climatic regions and farming situations. Frontline demonstrations are conducted in a block of two or four hectare land in order to have better impact of the demonstrated technologies on the farmers and field level extension functionaries. The agricultural technology is not generally accepted by the farmers completely in all respects.

As such there always appears to be a gap between the recommended technology by the scientist and it's modified from at the farmer's level. The technology gap is thus the major problem in the efforts of increasing agricultural production in the country. A need of the day is to reduce the technological gap between the agricultural technology recommended by the scientist and its acceptance by the farmers on their field.

In view of the above factors, frontline demonstrations were undertaken in a systematic manner on farmer's field to show the worth of a new variety and convince the farmers to adopt improved cultivation practices of wheat for increasing productivity of wheat. Keeping in view the present investigation attempts to study the yield gap between frontline demonstration trails and farmers yield, extend of technology adoption and benefit cost ratio.

\section{Materials and Methods}

The study was carried out by Krishi Vigyan Kendra, Nohar, Hanumangarh-II (Rajasthan) during Rabi 2012-13 to 2014-15 (three consecutive years) at farmer's field of different villages. The data on output of high yielding variety of wheat crop and inputs used per hectare have been collected from the frontline demonstration trails conducted. All the participating farmers were trained on various aspects of wheat production technologies. Recommended agronomic practices and genuine seeds of wheat were used for frontline demonstrations in 0.5 hectare area per demonstration. A one fifth area was also devoted to grow local standard check. The frontline demonstrations were conducted by Krishi Vigyan Kendra from Rabi 2012-13 to 2014-15 in area of 18 hectare on 45 locations (farmers). Thus, a total of 45 demonstrations were selected. The data collected from the reports of frontline demonstrations conducted by the Krishi Vigyan Kendra on the production technology of wheat crop were used. These were compared with prevailing production technologies of wheat crop (which were taken in check plots). The performances of improved varieties with improved technologies evaluated closely by the organizing seasonal training, method of demonstrations, field days and by taking cropcut experiments. Regular diagnostic visit by the scientists helped in proper execution of demonstration as well as collection of farmer's opinion about the demonstration field. Production and economic data for frontline demonstrations and local practice were collected and analyzed.

In the present study, technology index was operationally defined as the technical feasibility obtained due to implementation of frontline demonstration in wheat. To estimate the technology gap, extension gap and 
technology index following formulae used by Samuel et al., (2000) have been used:

Extension Gap $(\mathrm{kg} / \mathrm{ha})=$ Demonstration yield - Farmer practices yield (Local check)

Technology Gap $(\mathrm{kg} / \mathrm{ha})$ = Potential yield Demonstration yield

Technology Index = Potential yield Demonstration yield / Potential yield X 100

\section{Results and Discussion}

\section{Performance of Frontline demonstration}

Perusal of data indicated that the average yield of wheat increased progressively over the years of study in demonstration plots as well as in control plots. Highest grain yield was recorded during 2013-14 and lowest during 2012-13 (Table-1). Average grain yield of wheat under demonstration plots was 4293 $\mathrm{kg} / \mathrm{ha}$ when compared to local check 3933 $\mathrm{kg} / \mathrm{ha}$. The average percentage increase in the yield over local check was $9.24 \%$. More and less similar yield enhancement in different crops in front line demonstration has amply been documented by Hirenmath et al., (2007) and Patel et al., (2013). From these results it is evident that the performance of improved variety was found better than the local check under same environment conditions. Farmers were motivated by results of agro technologies applied in the frontline demonstrations trails and it is expected that they would adopt these technologies in the coming years. Yield of the frontline demonstration trails and potential yield of the crop was compared to estimate the yield gaps which were further categorized into technology index.

\section{Technology gap}

The technology gap shows the gap in the demonstration yield over potential yield and it was $507 \mathrm{~kg} / \mathrm{ha}$ (Table-2). The frontline demonstrations were laid down under the supervision of scientists at the farmer's field. There exists a gap between the potential yield and demonstration yield.

This may be due the weather conditions. Hence, location specific recommendations are necessary to bridge the gap. These findings are similar to the findings of Patel et al., (2013).

\section{Technology index}

Technology Index shows the feasibility of the variety at the farmer's field. The lower the value of the technology index more is the feasibility. Results of the study depicted in Table- 2 revealed that the technology index value was $10.56 \%$. The results of the present study are in consonance with the findings of Singh et al., (2007) and Patel et al., (2013).

\section{Economic of frontline demonstration}

The economics of wheat production under frontline demonstrations were estimated and the results of the study have been presented in Table-3. The results of economic analysis of wheat production revealed that frontline demonstrations recorded higher gross return was recorded during 2013-14 and lowest during 2014-15 (Table-3). Average gross return of wheat under demonstration plots was Rs. 59904 per ha and net return Rs. 41154 per ha with higher benefit cost ratio (3.19) as compared to local checks. These results are in accordance with the finding of Hirenmath $e t$ al., (2007) and Hirenmath and Nagaraju (2009). Further, additional cost of Rs. 500 per ha in demonstration has increased additional net returns Rs. 4530 per ha with incremental benefit cost ratio 9.06 suggesting it's higher profitability and economic viability of the demonstration. More and less similar results were also reported by Hirenmath et al., (2007) Dhaka et al., (2010) and Patel et al., (2013). 
Table.1 Productivity of wheat crop under demonstration and farmer practice

\begin{tabular}{|r|l|c|c|c|}
\hline Year & $\begin{array}{c}\text { Name of } \\
\text { variety }\end{array}$ & \multicolumn{2}{|c|}{$\begin{array}{c}\text { A verage yield } \\
\text { (Kg/ha) }\end{array}$} & $\begin{array}{c}\text { \% increase } \\
\text { in over the } \\
\text { yield }\end{array}$ \\
\cline { 3 - 5 } & $\begin{array}{c}\text { Demonst } \\
\text { ration } \\
\text { plot }\end{array}$ & $\begin{array}{c}\text { Farmer } \\
\text { practice }\end{array}$ & \\
\hline 2012-13 & Raj-4037 & 4052 & 3850 & 5.25 \\
\hline $\mathbf{2 0 1 3 - 1 4}$ & Raj-4037 & 4438 & 4150 & 6.94 \\
\hline $\mathbf{2 0 1 4 - 1 5}$ & Raj-4037 & 4390 & 3800 & 15.53 \\
\hline A verage & 4293 & 3933 & 9.24 \\
\hline
\end{tabular}

Table.2 Yield, technology gap, technology index and extension gap of wheat grown under demonstration and local check

\begin{tabular}{|c|c|c|c|c|c|}
\hline Variables & $\begin{array}{c}\text { Yield } \\
\text { (Kg/ha) }\end{array}$ & $\begin{array}{c}\% \\
\text { Increas } \\
\text { e over } \\
\text { local } \\
\text { check }\end{array}$ & $\begin{array}{c}\text { Extension } \\
\text { Gap } \\
\text { (Kg/ha) }\end{array}$ & $\begin{array}{c}\text { Technology } \\
\text { Gap (Kg/ha) }\end{array}$ & $\begin{array}{c}\text { Technolo } \\
\text { gy Index } \\
(\%)\end{array}$ \\
\hline $\begin{array}{l}\text { Local } \\
\text { check }\end{array}$ & 3933 & - & - & - & - \\
\hline $\begin{array}{l}\text { Demonst } \\
\text { ration } \\
\text { (Raj- } \\
\text { 4037) }\end{array}$ & 4293 & 9.15 & 360 & 507 & 10.56 \\
\hline
\end{tabular}

Potential yield: $4800(\mathrm{Kg} / \mathrm{ha})$

Table.3 Economic analysis of demonstration plot and farmer practice

\begin{tabular}{|c|c|c|c|c|c|}
\hline \multirow{2}{*}{ Year } & \multicolumn{3}{|c|}{ Demonstration plot (Rs./ha.) } \\
\hline & $\begin{array}{c}\text { Gross } \\
\text { Cost }\end{array}$ & $\begin{array}{c}\text { Gross } \\
\text { Return }\end{array}$ & $\begin{array}{c}\text { Net } \\
\text { Return }\end{array}$ & $\begin{array}{c}\text { B:C } \\
\text { Ratio }\end{array}$ \\
\hline 2012-13 & 18750 & 56120 & 37370 & 2.99 \\
\hline 2013-14 & 18750 & 62132 & 43382 & 3.31 \\
\hline 2014-15 & 18750 & 61460 & 42710 & 3.28 \\
\hline A verage & 18750 & 59904 & 41154 & 3.19 \\
\hline Year & \multicolumn{3}{|c|}{ Farmer plot (Rs./ha.) } \\
\hline & Gross & Gross & Net & B:C \\
\hline & Cost & Return & Return & Ratio \\
\hline 2012-13 & 18250 & 53322 & 35072 & 2.92 \\
\hline $\mathbf{2 0 1 3 - 1 4}$ & 18250 & 58100 & 39850 & 3.18 \\
\hline $\mathbf{2 0 1 4 - 1 5}$ & 18250 & 53200 & 34950 & 2.92 \\
\hline A verage & 18250 & 54874 & 36624 & 3.01 \\
\hline
\end{tabular}


The finding of the study revealed that wide gap existed in potential and demonstration yield in high yield wheat varieties due to technology and extension gap in Hanumangarh district of Rajasthan. By conducting frontline demonstration was an effective tool for increasing the productivity of wheat crop. Improved technologies in frontline demonstrations enhanced yield and increase percent over the farmers practice in local check plots. This will substantially increase the income as well as the livelihood of the farming community. This created greater curiosity and motivation among other farmers who do not adopt improved practices of wheat cultivation. The demonstrations also built the relationship and confidence between farmers and scientist of Krishi Vigyan Kendra.

The study emphasizes the needs to educate the farmers in adoption of improved technology to narrow the extension gaps through various technology transfer centers. Therefore, it is suggested that these factors may be taken for considered to increase the scientific temperament of the farmers.

\section{References}

Anonymous (2014). "Agricultural statistics at a glance". Ministry of Agriculture, Department of Agriculture and cooperation, Directorate of Economics and Statistics, Government of India, pp. 68-69.

Balasubramanian, V., Adhya, T. K., Ladha, J. K. (2012.) "Enhancing eco-efficiency in the intensive cereal-based systems of the Indo-Gangetic Plains". Issues in Tropical Agriculture Eco efficiency From Vision to Reality. CIAT Publication, Cali, CO.

Dhaka, B. L., Meena, B. S. and Suwalka, R. L. (2010). "Popularization of Improved Maize production technology through frontline demonstrations in southeastern Rajasthan". Journal of Agri. Sci., 1(1):39-42.

Hiremath, S. M. and Nagaraju, M. V. (2009). "Evaluation of frontline demonstration trails on onion in Haveri district of Karnataka”. Karnataka j. of agric. Sci., 22(5): 1092-1093.

Hiremath, S. M., Nagaraju, M. V. and Shashidhar, K. K. (2007). "Impact of frontline demonstration on onion productivity in farmers field". Nation. Sem. Appropriate Extn. Strat. Manag. Rural Resources, Univ. agric. Sci. Dharward. December 18-20:100.

Iftikhar, M. H., Shamshad, H. S., Hussain, S. and Iqbal, K. (2002). "Growth, yield and quality response of three wheat (Triticum aestivum L.) varieties to different levels of $\mathrm{N}, \mathrm{P}$ and $\mathrm{K}$ ". International journal of Agricultural biology. 4: 362-364.

Patel, M. M., Jhajharia, A. K., Khadda, B. S. and Patil, L. M. (2013). "Frontline demonstration: An effective communication approach for dissemination of sustainable cotton production technology". Ind. J. Extn.Edu. \& R.D., 21: 60-62.

Samuel, S. K., Miha, S., Roy, D. K., Mandal, A. K. and Saha, D. (2000). "Evaluation of Frontline demonstration on groundnut". Journal of Indian Society Coastal Agril. Res., 18:180-183.

Sarwar, N., Maqsood, M., Mubeen, K., Shehzad, M., Bhullar, M. S., Qamar, R., and Akbar, N. (2006). "Effect of different levels of irrigation on yield and yield components of wheat cultivars". Pakistan Journal of Agricultural Science. 47: 371-734.

Sharma, R. N. and Sharma, K. C. (2004). "Evaluation of frontline demonstration trails on oilseeds in Baran district of Rajasthan". Madhya Pradesh Journal of Extn. Edu., 7: 94-95. 
Singh, D. K. Gautam, U. S. and Singh R. K. (2007). "Study on yield gap and level of demonstrated crop production technology in Sagar district". Ind. Res. J. Extn. Edu., 7(2\&3):94-95.

\section{How to cite this article:}

Akshaya Ghintala, Bheiru Singh, Mukesh Kumar Verma and Manohar Lal. 2018. Performance of Front Line Demonstration on the Yield of Wheat in Hanumangarh District of Rajasthan, India. Int.J.Curr.Microbiol.App.Sci. 7(09): 3477-3482.

doi: https://doi.org/10.20546/ijcmas.2018.709.431 